\title{
NEW BASIC CHROMOSOME NUMBERS FOR GENERA OF NEOTROPICAL FERNS ${ }^{1}$
}

\author{
FLORENCE S. WAGNER \\ Department of Botany, The University of Michigan, \\ Ann Arbor 48109
}

\section{A B S T R A C T}

\begin{abstract}
Chromosome numbers for eight genera of Costa Rican ferns are reported here for the first time. These are: Neurocallis, $n=58$; Marginariopsis, $n=35$; Dicranoglossum, $n=36$; Glyphotaenium, $n=37$; Cochlidium, $n=33$; Ormoloma, $n=42$; Peltapteris, $n=40$; and Loxsomopsis, $n=46$. Chromosome observations involving several other genera are included: Solanopteris, $n=37$; Xiphopteris, $n=32 ;$ Hemidictyum, $n=31 ;$ Pleuroderris, $2 n=80$; Dictyoxiphium, $2 n=80$; and Polystichum, $n=41$. These numbers are compared to those of genera of presumed taxonomic affinity.
\end{abstract}

OUR KNOWLEDGE of the cytotaxonomy of Neotropical ferns, which essentially began with the publication of Walker's survey of Jamaican pteridophytes (1966, 1973a), has been extended in other areas of the New World tropics, in Mexico by Mickel, Wagner and Chen (1966) and Smith and Mickel (1977), and in Brazil by Tryon, Bautista and Araujo (1975). Individual monographic studies and taxonomic papers have further augmented the list of known chromosome numbers. A summary of the present state of our information can be found in the study of "Evolutionary Patterns and Processes in Ferns" (Lovis, 1977) which contains a list of the basic chromosome numbers of fern genera. According to the classification by Lovis, there remain 80 genera (including a few designated as subgenera) for which cytological observations have not been published. Approximately 25 of these are New World genera. This report presents chromosome numbers for 11 of these previously uncounted genera in Lovis' list, including for the sake of completeness several in which reports have been only recently published. I also include discussion of certain unusual new numbers that differ from those previously reported in some genera. Brief comments are added, where appropriate, on distinctive taxonomic characters.

\footnotetext{
Received for publication 27 July 1979; revision accepted 16 November 1979

I acknowledge the constant and generous help afforded me by Luis Diego Gómez P., Director of the Museo Nacional de Costa Rica, and by W. H. Wagner, Jr. Further studies of species reported here and other Central American ferns in collaboration with these two are being carried out as part of an NSF Latin American Cooperative Science Grant INT78-19909. I am also indebted to David B. Lellinger of the U.S. National Herbarium for identifications of several species in this report, to Alan R. Smith for suggested revisions, and to Jean Hazen for laboratory assistance.
}

Materials AND METHODS-All of the chromosome counts to be reported here were obtained from plants growing in Costa Rica. Fertile parts of fronds collected in the field were placed, at the end of each day's field trip, in small bottles containing a saturated solution of paradichlorobenzene, and refrigerated at ca. $4 \mathrm{C}$. After $24 \mathrm{hr}$ or less, excess water was blotted from the fertile leaf fragments, which were then put in Newcomer's Solution, left at room temperature overnight, and placed in a freezer in the morning. Chromosome studies were carried out at the University of Michigan using ACH (50\% acetocarmine:50\% Hoyer's Solution) as a squashing and mounting medium.

All collections were made by $\mathrm{W} . \mathrm{H}$. and $\mathrm{F}$. S. Wagner and L. D. Gómez P. (with the exception of Peltapteris foeniculacea) and are represented by duplicate vouchers (in the field number series of W. H. Wagner) both in the University of Michigan Herbarium (MICH) and in the Herbario Nacional of the Museo Nacional, San José, Costa Rica (CR).

OBSERVATIONS-The observations are arranged according to the sequence presented by Lovis (1977, p. $261 \mathrm{ff}$.).

\section{NEUROCALLIS Fée}

Neurocallis praestantissima (Bory) Fée (Fig. 1, 13)-C. R. Heredia Prov. Slopes of Volcán Barba, Zurquí, steep rainforest along stream, 13 March 1979, Wagner 79058. The monotypic genus Neurocallis is a rare and local fern of mountain rainforests in the West Indies, Costa Rica and Colombia. Neurocallis praestantissima has simple-reticulate venation (i.e., without included veinlets), and dimorphic, nearly acrostichoid fertile fronds-these characters distinguishing it from most of the 


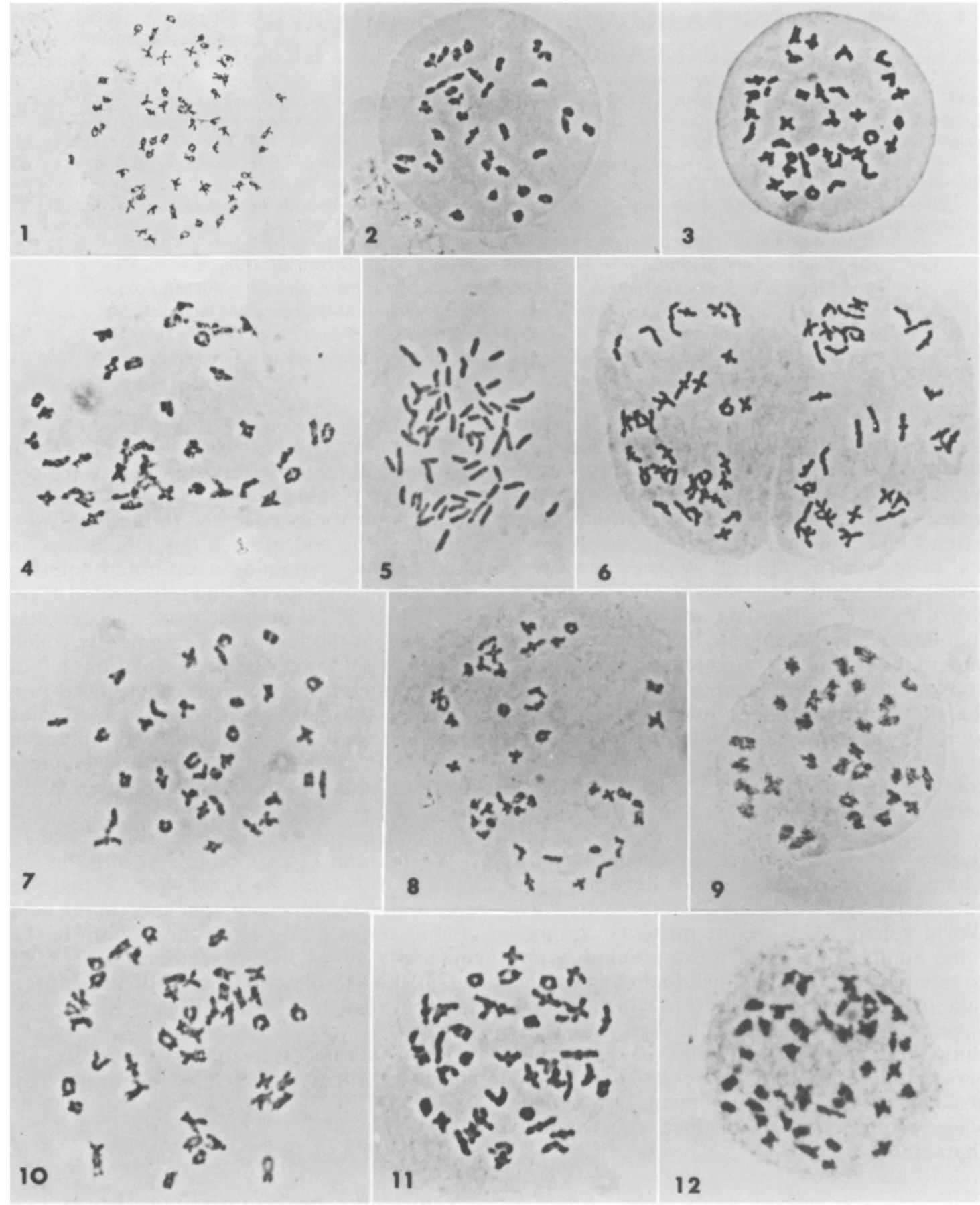

Fig. 1-12. Photographs of chromosomes. Fig. 13-24. Corresponding interpretations of chromosome figures. 1,13. Neurocallis praestantissima (Bory) Fée, $n=58, \times 270.2,14$. Marginariopsis wiesbaurii (Sodiro) C. Chr., $n=35$, $\times 610$. 3,15. Dicranoglossum panamense (C. Chr.) L. D. Gómez, $n=36, \times 670.4,16$. Glyphotaenium percrassum (Bak.) Copel., $n=37, \times 660$. 5,17. Xiphopteris limula Christ, $2 n=64, \times 830$. 6,18. Xiphopteris limula Christ, 2 cells, $n=32$, $\times 660$. 7,19. Cochlidium rostratum (Hook.) Maxon ex C. Chr., $n=33, \times 660.8,20$. Ormoloma standleyi 

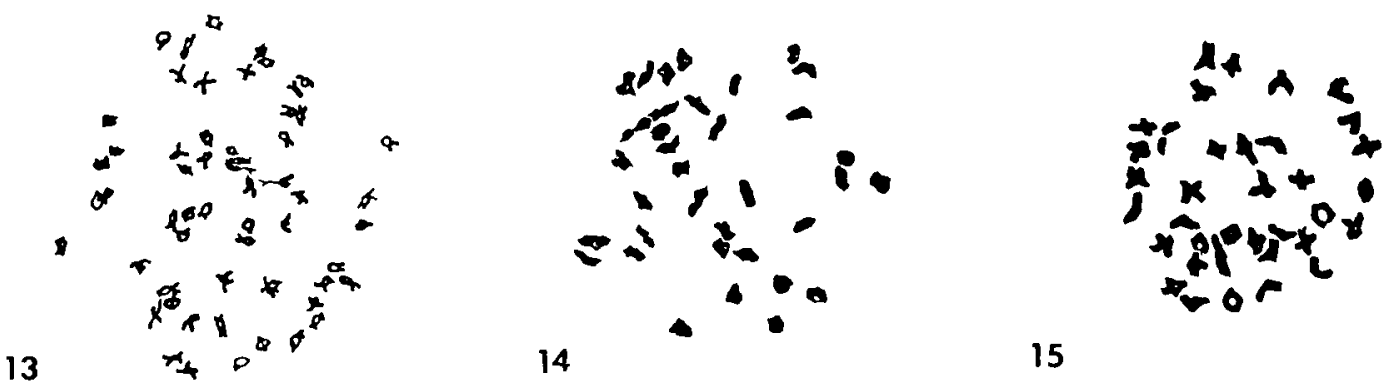

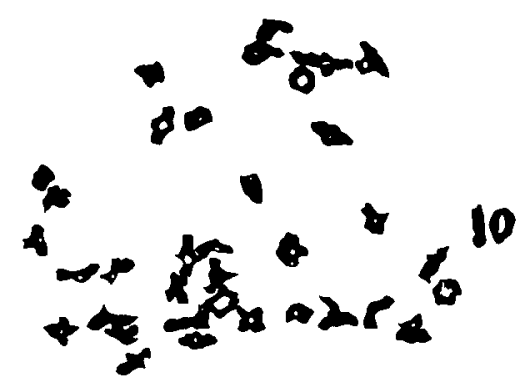

16

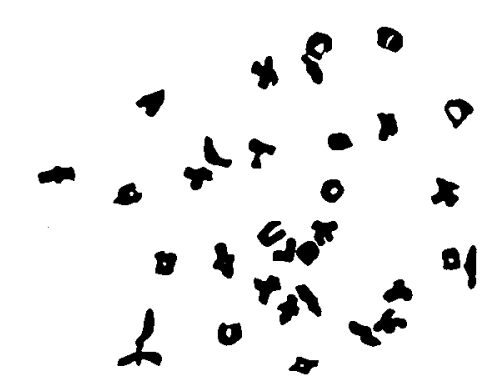

19

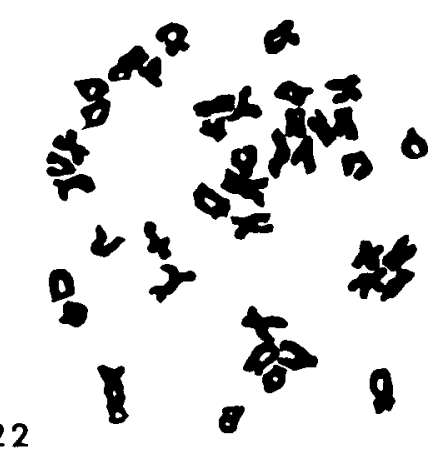

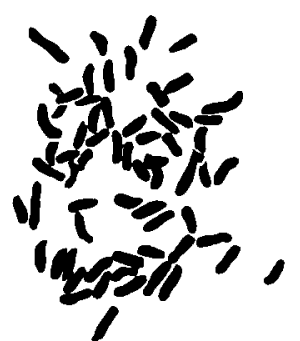

17

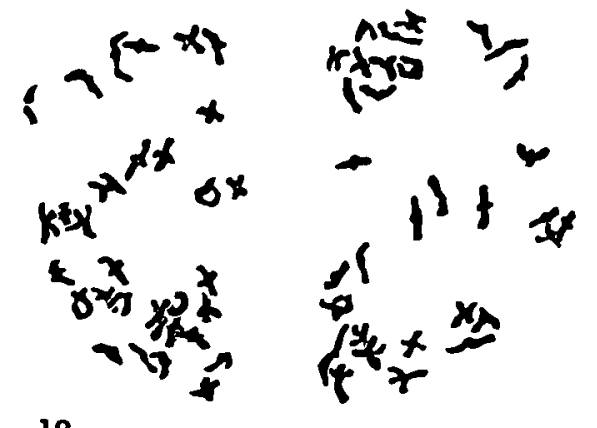

18
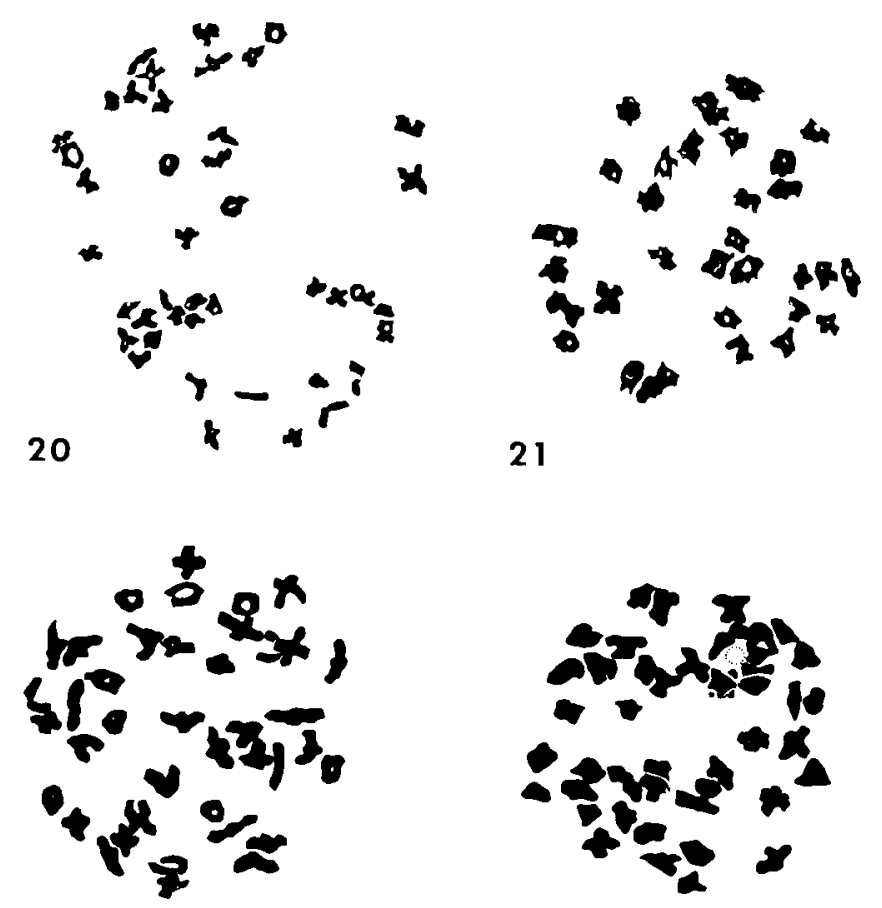

23

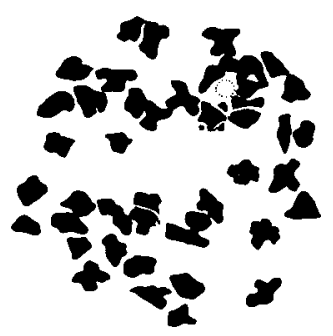

Maxon, $n=42, \times 610.9,21$. Hemidictyum marginatum (L.) Presl, $n=31, \times 720.10,22$. Polystichum dubium (Karst.) Diels, $n=41, \times 830$. 11,23. Peltapteris foeniculacea (Hk. \& Grev.) L. D. Gómez, $n=40, \times 670$. 12,24. Loxsomopsis costaricensis Christ, $n=46, \times 800$. 
species of its probable closest relative, Pteris. Meiotic material from Costa Rica has 58 pairs of chromosomes, a number consistent with our present theories of its affinities with Pteris, in which $x=29$. The Neotropical Pteris grandifolia L. has fronds similar to those of $\mathrm{Neu}$ rocallis, although they are not dimorphic. The venation pattern of $P$. grandifolia is unusual in having free veins that become reticulate in a band near the margin. A chromosome count, $n=58$, from Costa Rican material of this species (Limón Prov. Moín, 16 November 1977, Wagner 77577) is the same as that reported from Mexican and Jamaican material.

\section{MARGINARIOPSIS Christensen}

Marginariopsis wiesbaurii (Sodiro) C. Chr. (Fig. 2, 14)-C. R. Alajuela Prov. Road N from San Ramón to Balsa, 14 March 1977, Wagner 77063. Marginariopsis, a rare, monotypic genus of small epiphytes occurring in Costa Rica and Ecuador, has strongly dimorphic fronds, the fertile ones linear and coenosoral, the sterile ones lanceolate. The chromosome number of Marginariopsis wieshaurii is 35 pairs at meiosis. Relatively few Neotropical members of the Polypodiaceae have this number, the more usual chromosome complement being 37. Smith and Mickel (1977) have reported $n=35$ for Polypodium friedrichsthalianum Kunze from Costa Rica, and two Old World pleopeltids, Lepisorus (usually included in Pleopeltis) and Belvisia, have species with 35 pairs of chromosomes. In both of the latter genera, however, a tendency towards aneuploidy results in both lower and higher numbers in Lepisorus and a lower number in Belvisia (Lovis, 1977). At the present time, the number $n=35$ tends to support the separation of Marginariopsis from Pleopeltis.

DICRANOGLOSSUM J. Smith (syn. Eschatogramme Trev.)

Dicranoglossum panamense (C. Chr.) L. D. Gómez (Fig. 3, 15)—C. R. Limón Prov. Road to Chase, $5 \mathrm{~km}$ from Bribri, 17 November 1977 , Wagner 77588. Dicranoglossum, a genus comprising six species of small epiphytes of shaded forests, is found in the New World tropics from Cuba and Central America to Brazil. The upper fertile parts of the forked fronds are somewhat contracted and sporangia are borne in narrow coenosori along the margin. The chromosome number is 36 pairs at meiosis. Although most authors consider Dicranoglossum to be a close relative of Pleopeltis, the chromosome number usually associated with that genus in the New World, is 37 pairs. (Smith and Mickel, 1977, have found $P$. angusta in Mexico, however, to have 34 pairs at meiosis.) The chromosome number of Dicranoglossum is in fact uncommon among Neotropical polypodies.

\section{GLYPHOTAENIUM J. Smith}

Glyphotaenium percrassum (Bak.) Copeland (Fig. 4, 16)-C. R. Heredia Prov. Volcán Barba, above Porrosatí, 13 November 1977, Wagner 77517. Glyphotaenium (including Enterosora Baker) is a genus of small epiphytic grammitid ferms of Central America and northern South America, which characteristically have thick, spongy leaf tissue and impressed or immersed sori. Glyphotaenium percrassum has a chromosome number of 37 pairs. Copeland (1947) has suggested that Glyphotaenium may be derived from Grammitis trifurcata (L.) Copel. That species also has 37 pairs (Walker, 1966).

\section{COCHLIDIUM Kaulfuss}

Cochlidium rostratum (Hooker) Maxon ex C. Chr. (Fig. 7, 19)-C. R. Cartago Prov. San Cristóbal, 15 November 1978, Wagner 78574. Cochlidium is a genus of small epiphytes of the West Indies and Mexico to South America. Cochlidium rostratum is one of two out of 16 species (Bishop, 1978) to bear coenosori deeply immersed in a central groove. Its chromosome number is 33 pairs at meiosis. The most frequently encountered number in members of the Grammitidaceae is 37 . However, Walker (1966) found 33 pairs of chromosomes in Grammitis hartii (Jenm.) Proctor. (A still lower number for a member of the Grammitidaceae is reported below.)

\section{XIPHOPTERIS Kaulfuss}

Xiphopteris limula Christ (Fig. 5, 6, 17, 18)_C. R. Cartago Prov. Volcán Turrialba, Santa Cruz, 15 November 1977, Wagner 77552. Bishop (1978) placed Xiphopteris serrulata (Swartz) Kaulf., the type species of the genus, in Cochlidium, and the chromosome number of that species has been reported as 74 pairs. $^{2}$ Other authors have included the genus Xiphopteris in Grammitis, and it is placed there in Lovis' list. The taxonomic status of Xiphopteris will not be considered in this paper, but I mention the genus here in connection with other low chromosome

\footnotetext{
- Walker (1966) gave $n=$ ca. 74 II's, and ca. $148 \mathrm{I}$ 's in other cells. In Löve, Löve and Pichi Sermolli (1977) the reported $2 n=144$ by Araujo is in error; the original publication (Araujo in Löve, 1976) records $n=74$.
} 
numbers that are turning up in the Grammitidaceae, i.e., Walker's count of $n=33$ in Grammitis hartii (1966), and in Cochlidium as reported above. Xiphopteris limula from Costa Rica has only 32 pairs of chromosomes at meiosis, the lowest number known at present among all grammitid ferns.

\section{ORMOLOMA Maxon}

Ormoloma standleyi Maxon (Fig. 8, 20)-C. R. Heredia Prov. Slopes of Volcán Barba, Zurquí, 12 March 1977, Wagner 77042. Ormoloma is a genus of poorly-known lindsaeoid ferns from the West Indies, and from Costa Rica to French Guiana. The species in Costa Rica, $O$. standleyi, has 42 pairs of chromosomes at meiosis. Most of the chromosome counts so far reported for the lindsaeoid ferns are only approximate numbers, and it may be that in some cases the difficulty lies in the reduced number of spore mother cells; Odontosoria, for example, has only four spore mother cells per sporangium, so that chances of finding correct stages of division are greatly reduced from the more usual numbers of eight or 16 spore mother cells. Ormoloma presents no special cytological problems (it has eight spore mother cells and 32 spores), but it is a rare fern not often encountered.

\section{HEMIDICTYUM Presl}

Hemidictyum marginatum (L.) Presl (Fig. 9, 21)—C. R. Cartago Prov. Chitaria, 15 March 1977, Wagner 77086. Chromosomes of the perplexing monotypic genus Hemidictyum of the West Indies and tropical America have been counted by Walker (1973b) and found to number 31 pairs at meiosis, an anomalous number in a fern thought probably, but by no means obviously, to be related to Athyrium (Lovis, 1977, p. 415). Costa Rican material confirms this count.

\section{POLYSTICHUM Roth}

Polystichum dubium (Karsten) Diels (Fig. $10,22)-C$. R. Heredia Prov. Volcán Barba, above Porrosatí, 13 November 1977, Wagner 77503. The very rare montane fern, Polystichum dubium, reaches its northernmost known limit on Volcán Barba in Costa Rica, and extends south to Peru. Because of its venation pattern, which ranges from simple to highly reticulate, it occupies a critical position in distinguishing the limits of the genera Polystichum, Phanerophlebia with only casual anastomoses when present, and Cyrtomium with predominantly reticulate venation. Detailed morphological and ecological studies of Polystichum dubium are currently being carried out. Its chromosome number counted in Costa Rican material is 41 pairs at meiosis, the prevailing number in that genus.

\section{PELTAPTERIS Link (syn. Rhipidopteris Schott)}

Peltapteris foeniculacea (Hk. \& Grev.) L. D. Gómez (Fig. 11, 23)-C. R. San José Prov. La Palma, Gómez s.n. This curious New World genus of small tropical epiphytes with dichotomously veined leaves is thought to be closely related to Elaphoglossum, and like it, is dimorphic and acrostichoid. It differs from Elaphoglossum, however, in its strong tendency to have flabellate leaf blades, and also in its chromosome number. I have counted two species of Peltapteris from Costa Rica, the one above and also $P$. peltata (Swartz) Morton (C. R. Heredia Prov. San Rafael Vara Blanca, 9 March 1971, Wagner 71062), and both have 40 pairs of chromosomes at meiosis, while all species of Elaphoglossum so far reported have 41 or 82 .

\section{LOXSOMOPSIS Christ}

Loxsomopsis costaricensis Christ (Fig. 12, 24)-C. R. Heredia Prov. Cerro Vueltas, N of Heredia, 5 March 1977, Wagner 77001. Two genera, Loxsoma in the Old World and Loxsomopsis in the New World, constitute a small perplexing family of terrestrial ferns, "resembling Trichomanes in the sorus, and Dennstaedtia in vegetative structure" (Copeland, 1947). In the classification followed by Lovis it appears among the Familia Incertae Sedis (Lovis, 1977).

The three Neotropical species of Loxsomopsis range from Costa Rica to Bolivia. Loxsomopsis costaricensis has 46 pairs of chromosomes at meiosis, a number suggestive of affinity to either the dennstaedtioid or lindsaeoid ferns. The monotypic genus Loxsoma from New Zealand has 50 pairs (Brownsey, 1975). It may be that Loxsoma and Loxsomopsis are more distantly related than previously supposed.

Discussion-Our knowledge of the taxonomy and cytology of most fern groups has now advanced to the point where we can predict with some certainty what the range of numbers will be. Further cytological investigations of the Grammitidaceae, however, may reveal unexpected results. Bishop (1978) suggested that the sporangia and stomata of Cochlidium rostratum are considerably larger than those of 
C. linearifolium (Desv.) Maxon ex C. Chr. The chromosome number reported above, 33 pairs in the former species, is unusually low for grammitid ferns (but cf. Xiphopteris limula above with 32 pairs); perhaps then $C$. linearifolium will turn out to be lower still.

For the sake of completeness three genera that were recorded as uncounted in Lovis' list of chromosome numbers should be added here. The first reported chromosome number of $\mathrm{So}^{-}$ lanopteris was published in 1976, based on a count I had made of Costa Rican material cultivated in Ann Arbor (F. Wagner, 1976). Solanopteris brunei (Wercklé ex Christ) W. H. Wagner has 37 pairs of chromosomes at meiosis.

The chromosome numbers of the intergeneric hybrid Pleuroderris michleriana (D. C. Eaton) Maxon and of one of its parents, Dictyoxiphium panamense Hooker, have been published (Wagner, Wagner and Gómez, 1978) since Lovis' list appeared. Pleuroderris michleriana is a sterile hybrid with a total of 80 chromosomes including a surprising number of pairs, from 17 to 35 , at meiosis. The pairing situation in Pleuroderris is comparable to various intrageneric hybrids in Polystichum (cf. Lovis, 1977, p. 353 ff.), but Pleuroderris is unusual in that it is an intergeneric hybrid. The first cytological observations to be reported on Dictyoxiphium panamense, one of its parents (the other is Tectaria incisa Cav.), showed a somatic count of 80 chromosomes, supporting its inclusion with tectarid ferns.

\section{LITERATURE CITED}

BISHOP, L. E. 1978. Revision of the genus Cochlidium (Grammitidaceae). Amer. Fern J. 68: 76-94.

BRownSEY, P. J. 1975. A chromosome count in Loxsoma. N. Z. J. Bot. 13: $355-360$

Copeland, E. B. 1947. Genera filicum. Chronica Botanica, Waltham, Mass.

LöVE, A. 1976. IOPB chromosome number reports. LIII Taxon 25: 483-500.

, D. Löve, and R. E. G. Pichi Sermolli. 1977. Cytotaxonomical atlas of the Pteridophyta. J. Cramer, Vaduz.

Lovis, J. D. 1977. Evolutionary patterns and processes in ferns. Ad. in Bot. Res. 4: 229-415.

Mickel, J. T., W. H. Wagner, JR., ANd K. L. Chen. 1966. Chromosome observations on the ferns of Mexico. Caryologia 19: 95-102.

Smith, A. R. AND J. T. Mickel. 1977. Chromosome counts for Mexican ferns. Brittonia 29: 391-398.

Tryon, A. F., H. P. Bautista, and I. da Silva ArAUjo. 1975. Chromosome studies of Brazilian ferns. Acta Amazonica 5: 35-43.

WAGNer, F. S. 1976. The chromosome number of Solanopteris brunei (Wercklé ex Christ) Wagner. Brenesia 9: 81-82.

WAGner, W. H., JR., F. S. WAGner, AND L. D. Gómez P. 1978. The singular origin of a Central American fern, Plearoderris michleriana. Biotropica 10: 254264.

WALKER, T. G. 1966. A cytotaxonomic survey of the pteridophytes of Jamaica. Trans. R. Soc. Edinburgh 66: 169-237.

- - 1973a. Additional cytotaxonomic notes on the pteridophytes of Jamaica. Trans. R. Soc. Edinburgh 69: 109-135.

. 1973b. Evidence from cytology in the classification of ferns. In A. C. Jermy, J. A. Crabbe, and B. A. Thomas [eds.], The phylogeny and classification of the ferns. J. Linn. Soc. London, Bot. 67, Suppl. 1: $91-110$. 